\title{
Perceptions Of Corporate Social Responsibility In The Capital Market
}

Hyunjung Choi, Sungkyul University, South Korea

Doocheol Moon, Yonsei University, South Korea

\begin{abstract}
This study investigates how capital market participants such as investors and financial analysts perceive corporate social responsibility (CSR) as improving earnings quality. Managers use CSR as a signal of future financial improvement, which causes companies to invest in CSR in the current period. An expectation of future financial improvement leads to increase in the quality of earnings because it curtails the incentive to engage in earnings management. In addition, CSR is a signal to increase the reputation of the firm. If a firm values its reputation, managers of a CSR firm would refrain from earnings management to avoid damage to its reputation. We use a sample of Korean listed companies for the period 2002-2011 and a proxy for CSR involvement based on the Korea Economic Justice Institute index. When we use earnings response coefficients (ERCs) to measure investors' perceptions of earnings quality, we find that ERCs are higherfor firms with engagement in CSR activity. Further, when we use the predictive ability of past earnings in forecasting future earnings to measure analysts' perceptions of earnings quality, we find that the predictive ability of past earnings is higher when firms engage in CSR. Our results provide evidence that capital market participants perceive CSR as a signal of improved earning quality.
\end{abstract}

Keywords: Corporate Social Responsibility (CSR); Perception of Earnings Quality; Earnings Response Coefficient (ERC); Earnings Forecasts

\section{INTRODUCTION}

orporate social responsibility (CSR) has been conceptualized in a number of studies. At the initial stage, CSR is defined as a social contribution (Levitt 1958) or is evaluated in terms of ethical performance (Friedman 1970). Recent studies treat the concept as an interaction between business and society (Porter and Kramer 2006; Bessen et al. 2005). For example, the Enron Corporation, which was associated with a large-scale accounting scandal, was thought to have faithfully fulfilled its social responsibility because of its contribution to many different socialcauses - until its accounting fraud was detected. After the Enron accounting scandal, the concept of CSR began to change. Not only a corporation's social contribution, but also its corporate sustainability, management practices, and governance came to be considered as part of CSR (Kim et al. 2012; Burkett et al. 2006; Linthicum et al. 2010).

Reflecting this additional awareness, various international organizations have provided definitions, standards, and regulations regarding CSR. In particular, the International Organization for Standardization (ISO, 2010) officially published international guidelines for social responsibility, the ISO 26000. From an accounting perspective, the InternationalFederation of Accountants (IFAC2006a, 2006b) and the American Institute of Certified Public Accountants (AICPA 2010) define CSR in terms of sustainability, which results from accounting transparency. Further, the AICPA (1994) suggest that current financial statements may not reflect the real value of a company properly, and should therefore be supplemented by non-financial information such as the disclosure of CSR activity.

The purpose of this study is to examine how the capital market participants perceive CSR from an accounting point of view. Recently CSR has been regarded as a type of signal by which managers convey private information about the company. Lys et al. (2012) find that CSR is a signal of managers' expectations of future financial improvement. They suggest that although CSR investment may not directly improve financial performance, anticipation of future financial performance causes companies to invest in CSR in the current period. Further, we expect that CSR can signalimproved earnings quality for two reasons. First, a company with poorfinancial performance may overstate earnings to mask its 
financial status (McNichols and Stubben 2008; Dharan and Lev 1993). Anticipation of future financial improvement can improve the quality of earnings because it curtails the incentive to engage in earnings management. Second, CSR provides a positive signal for reputation of the firm (e.g., Verschoor 2005; Linthicum et al. 2010). Managers who value firm reputation highly tend to avoid engaging in socially unacceptable activities to secure that reputation. Therefore, managers of a CSR firm are likely to refrain from earnings management to protect its reputation (Kim et al. 2012). Thus, we posit a situation in which a company invests in CSR in expectation of high-quality financial reports. In particular, we examine the perception of CSR by key stakeholders such as investors and analysts.

We use a sample of Korean listed companies for the period 2002-2011 and a proxy for CSR involvement based on the Korea Economic Justice Institute (KEJI) index. First, using earnings response coefficients (ERCs) from regressions of returns on earnings to measure investors' perceptions of earnings quality, we find that investors perceive earnings quality to be higher with the commitment to CSR activity. In addition, investors are willing to pay a premium for higher quality of earnings. Second, using earnings coefficients from future earnings forecasts -reported earnings regressions to measure analysts' perceptions of earnings quality, we find that financial analysts also perceive earnings quality as improving with the commitment to CSR activity. Our results provide evidence that capital market participants perceive CSR as a signal of improved earnings quality.

This study contributes to the CSR literature as follows. Previous studies about the effect of CSR on the capital market focus on stock value, forecast accuracy, and the cost of capital (Hwang 2009; Ioannou and Serafeim 2010; Na and Hong 2011; Ghoul et al. 2011; Dhaliwal et al. 2011; Dhaliwal et al. 2012). Very few previous studies examine the usefulness of CSR-related information as recognized by capital market participants. We examine the perceptions of investors and financial analysts in terms of the relationship between CSR and earnings quality. Extending Lys et al. (2012) who suggest that CSR signals managers' expectations of future financial improvement, we provide evidence that CSR involvement may signal the usefulness of accounting information.

In the next section, we discuss the literature review and develop our hypotheses. We then describe our re search design used to test the hypotheses in Section 3, and discuss the sample in Section 4. Section 5 provides the empirical results. The final section concludes the paper.

\section{PREVIOUS LITERATURE AND HYPOTHESES}

CSR activity has been regarded as a signal by which managers convey private information about a company, as distinguished from casual interpretations (Lys et al. 2012). Signal plays a very important role in the capital market. According to signaling theory, companies send signals about their existence and identities where information asymmetry exists (Spence 1973, 1974). In particular, they try to provide sufficient information to counteract undervaluation caused by adverse selection. A company listed in the stock market may choose to provide more information than what is required by law or more information than average. Even the fact that no information is provided functions as a signal (Campbell et al. 2001). Lys et al. (2012) find a positive association between financial performance and CSR investment. This positive association is likely due to the signal value of CSR investment. They suggest that CSR investment does not in itself improve financial performance; however, the anticipation of future financial performance drives companies to invest in CSR activity in the current period. Thus, engagement in CSR activity is a signal of managers' expectations of future financial improvement. Further, CSR investment can signal future earnings quality. A company with poor financial performance may overstate earnings to mask its financial status (McNichols and Stubben 2008; Dharan and Lev 1993). Alternatively, anticipation of future financial improvement can improve the quality of earnings because it stabilizes earnings and curtails the incentives to engage in earnings management.

CSR activity provides a positive signal regarding the reputation of the firm (e.g., Verschoor 2005; Linthicum et al. 2010). The managers of a firm that value its reputation are likely to refrain from engaging in unethical activities. Kim et al. (2012) and Choi and Moon (2013) find a negative association between CSR and earnings management. They suggest that firms that prioritize CSR behave responsibly in order to curtail earnings management, thereby delivering more transparent and reliable financial information to stakeholders. Thus, CSR investment may signal managers' expectations of improved earnings quality. 
In this study, we investigate the perception of CSR by capital market participants and its potential to improve earnings quality. We first analyze how investors recognize CSR as it is reflected in stock price. Investors are key stakeholders who use corporate financial and non-financial information to evaluate firm performance. According to previous studies (Schipper and Vincent 2003; Teoh and Wong 1993), investors perceive the quality of earnings to be high when earnings are stable and improving in the future. They may be willing to pay a premium in these circumstances. If a company engages in CSR activity to distinguish itself from other companies, investors may recognize CSR activity as a signal of higher earnings quality. Thus, we expect that investors will perceive accounting information about companies that engage in CSR activity to be more useful than that about companies that do not engage in CSR activity. The preceding discussion leads to the following hypothesis.

Hypothesis 1. Investors perceive earnings quality as being improved by engagement in activity related to corporate social responsibility.

Financial analysts deliver information regarding the predicted value related to future earnings of a company to investors, acting as information mediators which solve the problems of information asymmetry (Campbell and Kracaw 1980). The corporate value-related information reflected in their reports has a significant effect on stock pricing (Francis and Soffer 1997; Schipper 1991; Brown et al. 1987). Financial analysts are likely to respond to information about CSR activity. Dhaliwal et al. (2012) state that many financial analysts tend to show interest in companies that engage in CSR activity because these companies publicly announce more information than those that are not involved in CSR activity. Ioannou and Serafeim (2010) state that the more a company engages in CSR activity, the more investment recommendations it receives from analysts. Thus, financial analysts can naturally tend to use information about CSR activity in forecasting earnings because of uncertainty and information asymmetry surrounding capital market. Analysts may perceive that CSR serves as a signal of high quality of earnings because CSR is the symbolic representative of credibility of financial information and improvement of future financial performance. Accordingly, our second hypothes is is as follows:

Hypothesis 2. Analysts perceive earnings quality as being improved by engagement in activity related to corporate social responsibility.

\section{RESEARCH METHODOLOGY}

\subsection{Investors' Perceptions}

To examine whether investors perceive earnings quality as being affected by signals related to CSR, we estimate the following equation which is similar to the research methodology of Ghosh and Moon (2005):

$$
\begin{aligned}
& \operatorname{RET}_{t}=\alpha+\beta_{1} E_{t}+\beta_{2} \Delta E_{t}+\beta_{3} E_{t} \times D C S R_{t}+\beta_{4} \Delta E_{t} \times D C S R_{t}+\beta_{5} D C S R+\sum_{j=1}^{6} \beta_{6+2(j-1)} E \times \\
& \text { Control Variables }{ }_{j}+\sum_{j=1}^{6} \beta_{7+2(j-1)} \Delta E \times \text { Control Variables }{ }_{j}+\sum_{j=1}^{6} \beta_{17+j} \text { Control Variables }_{j}+ \\
& \text { Industry/Year Dummies }+\varepsilon
\end{aligned}
$$

We use the 12-month buy-and-hold abnormal returns ending three months after the fiscal year-end (RET) as the dependent variable in Equation (1). $\mathrm{E}$ is net income and $\Delta \mathrm{E}$ is the difference in net income between current and last years. Both $E$ and $\Delta E$ are divided by the beginning of the year market value of equity. We add both measures in our regression model to increase the explanatory power and magnitude of ERCs by reflecting transitory and permanent components of earnings (Ghosh and Moon 2005; Easton and Harris 1991; Ali and Zarowin 1992). DCSR is an indicator variable for the company ranked in the KEJI index. Each control variable is interacted with $\mathrm{E}$ and $\Delta \mathrm{E}$ and is included on Equation (1).

The sum of earnings levels and changes in coefficients $\left(\beta_{1}+\beta_{2}\right)$, ERC, is our measure for investor perceptions of earnings quality. In this study, our focus is on the sum of the $\operatorname{E} \times \mathrm{DCSR}$ and $\triangle \mathrm{E} \times \mathrm{DCSR}$ coefficients $\left(\beta_{3}+\beta_{4}\right)$. If 
investors perceive earnings quality as improving (declining) with the engagement of a company in CSR activity, $\beta_{3}+$ $\beta_{4}$ is expected to be greater (less) than zero.

We include various control variables which are associated with ERC. A firm's maturity influences earnings quality and older firms are more likely to be stable and have fewer problems with information asymmetry, which suggests higher ERCs (Ghosh and Moon 2010). Thus, we include AGE measured by the natural logarithm of one plus the number of years a firm has been incorporated. Large auditors are generally more effective in constraining earnings management and provide higher quality audits (e.g., Becker et al. 1998; Teoh and Wong 1993). Thus, we control for BIG4, which equals one when the firm is audited by a Big 4 auditor and zero otherwise. We include MB and BETA in our regression model, motivated by valuation considerations (Warfield et al. 1995). MB is the market-to-book ratio defined as the market value of assets (sum of the market value of equity and the book value of debt) divided by the book value of total assets, and BETA is market risk estimated from 60 prior monthly stock returns. Large firms are likely to be exposed to more political costs and try to reduce political costs arising from high profitability, which affects earnings quality. Thus, we control for SIZE, which is the logarithmic transformation of total assets. Highly leveraged firms tend to have more incentives to avoid potential debt-covenant violations, which also affects earnings quality (DeFond and Jiambalvo 1994). Thus, we include LEV, which is the ratio of total debt to totalassets. In addition, we include industry and year fixed effects.

\subsection{Analys ts' Perceptions}

To examine the influence of commitment to CSR activity on financial analysts' perceptions of earnings quality, we estimate Equation (2) following Ghosh and Moon (2005):

$$
\begin{aligned}
& \text { FEPS }_{t}=\alpha+\beta_{1} \text { EPS }_{t-1}+\beta_{2} \Delta E P S_{t-1}+\beta_{3} \text { EPS }_{t-1} \times D C S R_{t-1}+\beta_{4} \Delta E P S_{t-1} \times D C S R_{t-1}+\beta_{5} D_{C S R_{t-1}}+ \\
& \sum_{j=1}^{7} \beta_{6+2(j-1)} \text { ExControl Variables } j+\sum_{j=1}^{7} \beta_{7+2(j-1)} \Delta E \times \text { Control Variables }_{j}+ \\
& \sum_{j=1}^{7} \beta_{19+j} \text { Control Variable } s_{j}+\text { Industry/Year Dummies }+\varepsilon
\end{aligned}
$$

FEPS ${ }_{t}$ is the mean annual earnings per share (EPS) forecast for year $t$ issued after the release of earnings for year $t-$ 1. We use reported EPS and changes in EPS $\left(E P S_{t-1}\right.$ and $\left.\triangle E P S_{t-1}\right)$ instead of $E$ and $\triangle E$ in Equation (1). $E P S_{t-1}$ is actual annualEPS for year $\mathrm{t}-1 . \triangle E P S_{t-1}$ is the absolute change in reported EPS for year $\mathrm{t}-1$, which is the difference in annual EPS between year $\mathrm{t}-1$ and year $\mathrm{t}-2\left(\left|E P S_{t-1}-E P S_{t-2}\right|\right)$. When a large earnings surprise is transitory, the predictive power of past earnings in forecasting future earnings is low (Barron et al. 2002). Thus, we include both $E P S_{t-1}$ and $\triangle E P S_{t-1}$ in Equation (2).

We include the control variables which affect analysts' incentives to acquire information about future earnings (e.g., Baron et al. 2002; Lang and Lundholm 1996). Older firms are likely to have more stable financial performance, and thus it is easier to predict earnings for older firms. Thus, we control for AGE measured by the natural logarithm of one plus the number of years a firm has been incorporated. Analysts perceive earnings quality as improving for firms which are audited by big auditors (Barron et al. 2002; Lang and Lundholm 1996). Thus, we include BIG4 in our regression model, which equals one when the firm is audited by a Big 4 auditor and zero otherwise. Firms with high growth opportunities tend to have high information asymmetry and thus less rely on reported earnings in predicting earnings (Barron et al. 2002; Lang and Lundholm 1996). Thus, we include the market-to-book ratio of assets (MB) computed as the market value of as sets (sumof the market value of equity and the book value of debt) divided by the book value of total as sets. To control for the risk, we include both a market-based measure and an accounting-based measure. BETA is market risk estimated from 60 prior monthly stock returns, and LEV is financial leverage computed as the ratio of total debt to total assets. Large firms tend to have more information available to investors than small firms and thus firm size is related to the predictability of future earnings (DeFond and Hung 2003; Barron et al. 2002). We include SIZE, which is measured as the natural logarithm of total as sets. We further include COVERA GE, which is measured as the number of analysts following the firm (Lang and Lundholm 1996). We measure our explanatory variables including DCSR at the end of year $\mathrm{t}-1$. 


\subsection{Sample Selection}

4. DATA

To examine the effects of CSR engagement on the perception of participants in the capital market, we begin by collecting information on CSR activity. We identify CSR companies by being included in the list of the top 200 best corporate citizens from 2002 to 2011 published by the Korea Economic Justice Institute (KEJI), a leading CSR rating agency in Korea. ${ }^{1}$

The empirical analysis includes a set of non-financial and unregulated KOSPI (equivalent to NYSE) listed companies for the period 2002 to 2011. We supplement the KEJI data with financial data from KISVALUE. Stock returns and analysts' forecast data are obtained from the FN Guide. We exclude merged, acquired, and delisted companies from the Korean stock market. Additionally, we exclude companies for which no data was available. As a result, the final sample includes 5,388 company-year observations for the analys is of investors'perceptions and 1,982 company-year observations for the analysis of analysts' perceptions. To remove the effects of outliers, we winsorize all continuous variables at the top and bottom 1 percentile.

\subsection{Descriptive Statistics}

Table 1 reports the descriptive statistics for the sample, including the mean, first quartile, median, third quartile, and standard deviation for all variables. The mean (median) RET is $0.185(0.057)$, while the mean (median) $\mathrm{E}$ and $\Delta \mathrm{E}$ are $0.084(0.096)$ and $0.047(0.005)$, respectively. The mean (median) FEPS is 5.941 (2.865) thousand won, the mean (median) EPS is 4.808 (1.967) thousand won, and the mean (median) $\triangle \mathrm{EPS}$ is $0.514(0.150)$ thousand won. More than $33 \%$ of all observations (i.e., $33.8 \%$ ) are involved in CSR.

For the control variables, the mean AGE is 36.8 years. Almost $58.6 \%$ of the companies in the sample are audited by large auditors (BIG4). The mean (median) values for the other variables, market-to-book ratio (MB), systematic risk (BETA), total assets (TA), and debt ratio (LEV), are 1.011 (0.706), 0.931 (0.902), 1,440 (228) billion won, and 0.449 (0.454), respectively.

\footnotetext{
${ }^{1}$ The validity of the KEJI index is supported by its long history of publication (since 1991) and its extended use in Korean CSR studies (Hwang 2009; Chun and Kim 2010; Kim and Wi 2010; Oh et al. 2011; Yook and Choi 2011). The KEJI index is rated based on quantitative and qualit ative measures and is organized into seven major categories: environmental impact, community and society, corporate governance, corporate integrity, customers, employees, and long-term orientation.
} 
Table 1. Descriptive Statistics

\begin{tabular}{l|c|c|c|c|c}
\hline & Mean & Q1 & Median & Q3 & Std. Dev. \\
\hline RET & 0.185 & -0.210 & 0.057 & 0.406 & 0.623 \\
\hline $\mathrm{E}$ & 0.084 & 0.024 & 0.096 & 0.192 & 0.349 \\
\hline$\triangle \mathrm{E}$ & 0.047 & -0.057 & 0.005 & 0.081 & 0.498 \\
\hline FEPS (thousand won) & 5.941 & 1.210 & 2.865 & 6.248 & 9.243 \\
\hline EPS (thousand won) & 4.808 & 0.636 & 1.967 & 5.072 & 9.077 \\
\hline$\triangle$ EPS (thousand won) & 0.514 & -0.658 & 0.150 & 1.285 & 4.757 \\
\hline DCSR & 0.338 & 0.000 & 0.000 & 1.000 & 0.473 \\
\hline AGE(year) & 36.788 & 29.000 & 37.000 & 46.000 & 15.185 \\
\hline BIG4 & 0.586 & 0.000 & 1.000 & 1.000 & 0.493 \\
\hline MB & 1.011 & 0.427 & 0.706 & 1.221 & 0.956 \\
\hline BETA & 0.931 & 0.630 & 0.902 & 1.199 & 0.421 \\
\hline TA (billion won) & 1.440 & 105 & 228 & 661 & 5.420 \\
\hline LEV & 0.449 & 0.299 & 0.454 & 0.591 & 0.197 \\
\hline COVERAGE & 7.766 & 2.000 & 5.000 & 13.000 & 7.030 \\
\hline Defin & & & &
\end{tabular}

\section{Definitions:}

RET: $\quad$ 12-month buy-and-hold abnormal returns ending three months after the fiscal year-end

E: $\quad$ Net income divided by the beginning of the year market value of equity

$\triangle \mathrm{E}: \quad$ Difference in net income bet ween current and last years divided by the beginning of the year market value of equity

FEPS: $\quad$ Mean annual EPS forecast for year $t$ issued after the release of earnings for year $t-1$ (thousand won)

EPS: $\quad$ Actual annual EPS for year $\mathrm{t}-1$ (thousand won)

$\triangle \mathrm{EPS}: \quad$ Absolute change in reported EPS for year $\mathrm{t}-1$, which is the difference in annual EPS bet ween year $\mathrm{t}-1$ and year $\mathrm{t}-2\left(\mid \mathrm{EPS}_{\mathrm{t}-\mathrm{I}^{-}}\right.$ $\mathrm{EPS}_{\mathrm{t}-2} \mid$ ) (thousand won)

DCSR: Indicat or variable that equals one for the company ranked in the KEJI index and zero otherwise

AGE: $\quad$ Natural logarithm of one plus the number of years the company has been incorporated

BIG4: Indicat or variable that equals one when the firm is audited by a Big 4 auditor and zero otherwise

MB: $\quad$ Market-to-book ratio computed as the market value of assets (sum of the market value of equity and the book value of debt) divided by the book value of total assets

BET A: $\quad$ Market risk estimated from 60 prior monthly stock returns

TA: $\quad$ Total assets (billion won)

SIZE: $\quad$ logarithmic transformation of total assets

LEV: $\quad$ Total debt divided by total assets

COVERAGE: Number of analysts following the firm

Table 2 presents the Pearson correlation matrix for the variables included in Equation (1). RET is positively correlated with $\mathrm{E}(0.174)$ and $\triangle \mathrm{E}(0.131)$, and $\mathrm{E}$ is also positively correlated with $\triangle \mathrm{E}(0.474)$. DCSR is positively correlated with $\mathrm{E}(0.147)$, consistent with the results of prior studies in which financial performance was directly or indirectly associated with commitment to CSR activity (Orlitzky et al. 2003; Orlitzky and Benjamin 2001; Hull and Rothenberg 2008; Beurden and Gössling 2008; Margolis and Walsh 2003; Guiral 2012; Surroca et al. 2010). The correlation between SIZE and BIG4 (0.281) is higher than any of the othercorrelations, excluding that between Eand $\triangle \mathrm{E}$. Overall, most explanatory variables are not highly correlated with each other. Therefore, multi-collinearity is not a problem.

Table 2. Pairwise Correlation Coefficients

\begin{tabular}{|c|c|c|c|c|c|c|c|c|c|c|}
\hline & RET & $\mathbf{E}$ & $\triangle \mathbf{E}$ & DCSR & AGE & BIG4 & MB & BETA & SIZE & LEV \\
\hline RET & 1.000 & & & & & & & & & \\
\hline $\mathrm{E}$ & $0.174^{* * *}$ & 1.000 & & & & & & & & \\
\hline$\triangle \mathrm{E}$ & $0.131^{* * * *}$ & $0.474^{* * * *}$ & 1.000 & & & & & & & \\
\hline DCSR & 0.019 & $0.147^{\ldots-\pi}$ & -0.011 & 1.000 & & & & & & \\
\hline AGE & -0.001 & -0.018 & -0.003 & $0.054^{* * * *}$ & 1.000 & & & & & \\
\hline BIG4 & 0.011 & $0.047^{2 \ldots-x}$ & 0.003 & $0.106^{* \ldots+\cdots}$ & $-0.041^{\text {wax }}$ & 1.000 & & & & \\
\hline MB & $0.130^{* * * *}$ & $-0.073^{* * *}$ & 0.018 & $0.055^{* * *}$ & $-0.143^{* * *}$ & $0.095^{* * *}$ & 1.000 & & & \\
\hline BETA & 0.016 & -0.080 & $0.023^{*}$ & -0.066 & -0.036 & $0.055^{\ldots \ldots}$ & $0.103^{n+\cdots}$ & 1.000 & & \\
\hline SIZE & 0.014 & $0.066^{* * * *}$ & -0.004 & $0.211^{* * * *}$ & $0.052^{* * *}$ & $0.281^{* * *}$ & $0.123^{* * * *}$ & $0.210^{* * * *}$ & 1.000 & \\
\hline LEV & 0.034 & $-0.197^{*}$ & $0.039^{\circ}$ & -0.203 & -0.010 & $0.037^{\circ}$ & 0.160 & 0.210 & $0.151^{\prime \prime}$ & 1.000 \\
\hline
\end{tabular}

The definitions of variables are provided in Table 1.

$*, * *, * * *$ indicate st atistical significance at $p<0.10, p<0.05$, and $p<0.01$ levels, respectively, based on two-tailed tests. 


\section{EMPIRICAL RESULTS}

\subsection{The Results for Hypothesis 1}

In Table 3, we report the findings from testing of how a company's commitment to CSR activity affects the returnsearnings association. Consistent with previous studies, reported earnings ( $\mathrm{E}$ and $\Delta \mathrm{E}$ ) are significantly and positively as sociated with returns; the ERC $\left(\beta_{1}+\beta_{2}\right)$ in Model (1) is $0.311(\mathrm{~F}=189.50)$. Furthermore, the sum of the coefficients of $\mathrm{E} \times \mathrm{DCSR}$ and $\triangle \mathrm{E} \times \operatorname{DCSR}\left(\beta_{3}+\beta_{4}\right)$ is positive and significant $(1.308, \mathrm{~F}=127.13)$. These results suggest that investors pay more for reported earnings when a company engages in CSR activity.

In Model (2) that includes various control variables, $\beta_{1}+\beta_{2}$ and $\beta_{3}+\beta_{4}$ both remain positive and significant; it is $0.455(\mathrm{~F}=237.57)$ and $1.246(\mathrm{~F}=119.56)$, respectively. After controlling for other variables in the model, our results hold that investors pay a premium for earnings for CSR companies. This evidence supports hypothesis 1 , suggesting that investors perceive earnings about companies that engage in CSR activity to be more informative than that of companies which do not.

Table 3. Earnings Response Coefficients and Perceptions of Investors

\begin{tabular}{|c|c|c|c|}
\hline \multirow[b]{2}{*}{ Variable } & \multirow[b]{2}{*}{ Coefficient } & \multicolumn{2}{|c|}{ Dependent Variable $=$ RET } \\
\hline & & Model (1) & Model (2) \\
\hline Intercept & $(\alpha)$ & $0.070(2.62)^{* * * *}$ & $-0.273(-1.85)^{*}$ \\
\hline $\mathrm{E}$ & $\left(\beta_{1}\right)$ & $0.251(10.00)^{* * *}$ & $0.385(11.72)^{* * * *}$ \\
\hline$\Delta \mathrm{E}$ & $\left(\beta_{2}\right)$ & $0.060(3.52)$ & $0.070(3.10)$ \\
\hline & $\left(\beta_{1}+\beta_{2}\right)$ & $0.311(189.50)^{\text {**** }}$ & $0.455(237.57)^{* * *}$ \\
\hline ExDCSR & $\left(\beta_{3}\right)$ & $0.620(5.09)^{3+\cdots}$ & $0.736(6.16)^{6 \cdot 7}$ \\
\hline$\triangle \mathrm{E} \times \mathrm{DCSR}$ & $\left(\beta_{4}\right)$ & $0.688(5.74)^{* * * *}$ & $0.510(4.34)^{* * * *}$ \\
\hline & $\left(\beta_{3}+\beta_{4}\right)$ & $1.308(127.13)^{\cdots \cdots n}$ & $1.246(119.56)^{\cdots \cdots}$ \\
\hline DCSR & $\left(\beta_{5}\right)$ & $-0.109(-4.78)^{* * * *}$ & $-0.138(-5.89)^{3 * * *}$ \\
\hline Control Variable: & & & \\
\hline $\operatorname{E} \times \operatorname{AGE}\left(\beta_{6}\right) / \Delta \mathrm{E} \times \operatorname{AGE}\left(\beta_{7}\right)$ & $\left(\beta_{6}+\beta_{7}\right)$ & & $-0.094(11.02)^{*}$ \\
\hline $\mathrm{E} \times \mathrm{BIG} 4\left(\beta_{8}\right) / \Delta \mathrm{E} \times \mathrm{BIG} 4\left(\beta_{9}\right)$ & $\left(\beta_{8}+\beta_{9}\right)$ & & $-0.034(6.16)^{* *}$ \\
\hline $\operatorname{E} \times \mathrm{MB}\left(\beta_{10}\right) / \Delta \mathrm{E} \times \mathrm{MB}\left(\beta_{11}\right)$ & $\left(\beta_{10}+\beta_{11}\right)$ & & $0.001(2.32)$ \\
\hline $\operatorname{EE} \times \operatorname{BETA}\left(\beta_{12}\right) / \Delta \operatorname{E} \times \operatorname{BETA}\left(\beta_{13}\right)$ & $\left(\beta_{12}+\beta_{13}\right)$ & & $4.909(6.45)^{* * *}$ \\
\hline $\operatorname{E} \times \operatorname{SIZE}\left(\beta_{14}\right) / \Delta \mathrm{E} \times \operatorname{SIZE}\left(\beta_{15}\right)$ & $\left(\beta_{14}+\beta_{15}\right)$ & & $0.011(7.89)^{* * *}$ \\
\hline $\operatorname{Ex} \operatorname{LEV}\left(\beta_{16}\right) / \Delta \mathrm{E} \times \operatorname{LEV}\left(\beta_{17}\right)$ & $\left(\beta_{16}+\beta_{17}\right)$ & & $-0.044(19.49)^{* * *}$ \\
\hline AGE & $\left(\beta_{18}\right)$ & & $0.020(1.66)^{*}$ \\
\hline BIG4 & $\left(\beta_{19}\right)$ & & $-0.000(-0.00)$ \\
\hline MB & $\left(\beta_{20}\right)$ & & $0.097(11.70)^{* * * *}$ \\
\hline BETA & $\left(\beta_{21}\right)$ & & $-1.244(-0.65)$ \\
\hline SIZE & $\left(\beta_{22}\right)$ & & $0.005(0.97)$ \\
\hline LEV & $\left(\beta_{23}\right)$ & & $0.067(1.60)$ \\
\hline Industry Dummy & & & Included \\
\hline Year Dummy & & & Included \\
\hline Adj. $R^{2}$ & & 0.281 & 0.326 \\
\hline F-Value & & $77.60^{* \cdots+4}$ & $57.41^{* \ldots * \pi}$ \\
\hline $\mathrm{N}$ & & 5,388 & 5,388 \\
\hline
\end{tabular}

The definitions of variables are provided in Table 1 .

$*, * * * * *$ indicate st atistical significance at $p<0.10, p<0.05$, and $p<0.01$ levels, respectively, based on two-tailed tests.

\subsection{The Results for Hypothesis 2}

Table 4 reports the results of regressions based on Equation (2). In the first column in Table 4 reporting the results of Model (1) without the control variables, actual earnings released just before the forecasts are positively associated with analysts' consensus forecast of earnings one year ahead. $\beta_{1}+\beta_{3}$ is positive and highly significant $(0.496, \mathrm{~F}=$ 534.15). Moreover, $\beta_{3}+\beta_{4}$ is also positive and significant $(0.318, F=83.11)$. Our results suggest that analysts rely more on reported EPS in forecasting EPS in the year ahead when a company engages in CSR activity. When we Copyright by author(s); $\underline{\text { CC-BY }}$ 
estimate Model (2) including a number of control variables, $\beta_{3}+\beta_{4}$ remains positive and significant $(0.209$, $F=$ 38.71). This evidence supports the second hypothesis that financial analysts perceive CSR as a signal of improved earnings quality.

Table 4. Analy st Earnings Forecasts and Perceptions of Information Intermediaries

\begin{tabular}{|c|c|c|c|}
\hline & & \multicolumn{2}{|c|}{ Dependent Variable $=$ FEPS } \\
\hline & Coefficients & Model (1) & Model (2) \\
\hline Intercept & $(\alpha)$ & $1.847(5.53)^{3+\cdots}$ & $-8.085(-4.23)^{*}$ \\
\hline EPS & $\left(\beta_{1}\right)$ & $0.961(60.60)^{\text {**** }}$ & $1.080(41.07)^{* * * *}$ \\
\hline$\triangle \mathrm{EPS}$ & $\left(\beta_{2}\right)$ & $-0.465(-18.93)^{* * *}$ & $-0.375(-11.33)^{* * *}$ \\
\hline & $\left(\beta_{1}+\beta_{2}\right)$ & $0.496(534.15)^{\ldots \ldots}$ & $0.705(413.03)^{-\cdots *}$ \\
\hline EPS $\times$ DCSR & $\left(\beta_{3}\right)$ & $0.066(3.27)^{3+\cdots}$ & $-0.009(-0.44)$ \\
\hline$\triangle \mathrm{EPS} \times \mathrm{DCSR}$ & $\left(\beta_{4}\right)$ & $0.252(6.43)^{* * *}$ & $0.218(5.82)^{* \cdots *}$ \\
\hline & $\left(\beta_{3}+\beta_{4}\right)$ & $0.318(83.11)^{* . * *}$ & $0.209(38.71)^{\text {*** }}$ \\
\hline DCSR & $\left(\beta_{5}\right)$ & $-0.571(-3.44)^{* * * * *}$ & $-0.344(-2.19)^{\text {*** }}$ \\
\hline \multicolumn{4}{|l|}{ Control Variables: } \\
\hline $\mathrm{EPS} \times \operatorname{AGE}\left(\beta_{6}\right) / \Delta \mathrm{EPS} \times \operatorname{AGE}\left(\beta_{7}\right)$ & $\left(\beta_{6}+\beta_{7}\right)$ & & $-0.018(0.66)$ \\
\hline $\mathrm{EPS} \times \mathrm{BIG} 4\left(\beta_{8}\right) / \Delta \mathrm{EPS} \times \operatorname{BIG} 4\left(\beta_{9}\right)$ & $\left(\beta_{8}+\beta_{9}\right)$ & & $0.107(24.25)^{* * *}$ \\
\hline $\mathrm{EPS} \times \mathrm{MB}\left(\beta_{10}\right) / \Delta \mathrm{EPS} \times \mathrm{MB}\left(\beta_{11}\right)$ & $\left(\beta_{10}+\beta_{11}\right)$ & & $0.018(9.67)^{* * * *}$ \\
\hline $\operatorname{EPS} \times \operatorname{BETA}\left(\beta_{12}\right) / \Delta \operatorname{EPS} \times \operatorname{BETA}\left(\beta_{13}\right)$ & $\left(\beta_{12}+\beta_{13}\right)$ & & $12.696(27.57)^{* * * *}$ \\
\hline $\operatorname{EPS} \times \operatorname{SIZE}\left(\beta_{14}\right) / \Delta \mathrm{EPS} \times \operatorname{SIZE}\left(\beta_{15}\right)$ & $\left(\beta_{14}+\beta_{15}\right)$ & & $-0.010(8.76)^{*-1}$ \\
\hline $\operatorname{EPS} \times \operatorname{LEV}\left(\beta_{16}\right) / \Delta \mathrm{EPS} \times \operatorname{LEV}\left(\beta_{17}\right)$ & $\left(\beta_{16}+\beta_{17}\right)$ & & $-0.052(1.92)$ \\
\hline $\operatorname{EPS} \times \operatorname{COVERAGE}\left(\beta_{18}\right) / \Delta \mathrm{EPS} \times \operatorname{COVERAGE}\left(\beta_{19}\right)$ & $\left(\beta_{18}+\beta_{19}\right)$ & & $0.001(0.23)$ \\
\hline AGE & $\left(\beta_{20}\right)$ & & $0.070(0.59)$ \\
\hline BIG4 & $\left(\beta_{21}\right)$ & & $-0.398(-2.27)^{\cdots}$ \\
\hline MB & $\left(\beta_{22}\right)$ & & $0.008(0.10)$ \\
\hline BETA & $\left(\beta_{23}\right)$ & & $-3.385(-1.82)^{*}$ \\
\hline SIZE & $\left(\beta_{24}\right)$ & & $0.354(4.79)^{* * * *}$ \\
\hline LEV & $\left(\beta_{25}\right)$ & & $1.080(2.35)^{* *}$ \\
\hline COVERAGE & $\left(\beta_{26}\right)$ & & $-0.021(-1.32)$ \\
\hline Industry Dummy & & & Included \\
\hline Year Dummy & & & Included \\
\hline Adj. $R^{2}$ & & 0.892 & 0.913 \\
\hline F-Value & & $596.15^{* * *}$ & $420.50^{* * *}$ \\
\hline $\mathrm{N}$ & & 1,982 & 1,982 \\
\hline
\end{tabular}

The definitions of variables are provided in Table 1.

$*, * *, * * *$ indicate statistical significance at $p<0.10, p<0.05$, and $p<0.01$ levels, respectively, based on two-tailed tests.

\subsection{Sensitivity Analyses}

Although third parties such as KEJI track and rate CSR activity, firms have become increasingly willing to disclose CSR reports voluntarily in recent years. There is a steadily increasing trend in the number of CSR reports over time (from 2 in 2003 to 47 in 2011). Although CSR performance ratings are available to investors and fin ancial analysts, ratings alone are unlikely to provide sufficient information for them to assess a firm's overall CSR performance. Voluntarily disclosing CSR activity demonstrates firms' confidence in their CSR performance, which sends a signal to investors and analysts (Dhaliwal et al. 2012). Therefore, voluntary CSR disclosures may provide additional information necessary for investors and analysts to assimilate these summary ratings. To control for the effect of voluntary CSR disclosure on capital market participants' perception beyond the information in CSR ratings, we additionally include an indicator variable (REPORT) that equals one when a firm voluntarily discloses a CSR report and zero otherwise in Equations (1) and (2).

In Panel A of Table 5, $\beta_{1}+\beta_{2}$ and $\beta_{3}+\beta_{4}$ both remain positive and significant in Model (2) even after controlling for the release of CSR reports; they are $0.452(\mathrm{~F}=233.71)$ and $1.236(\mathrm{~F}=117.61)$. The sum of the coefficients of $\mathrm{E} \times \mathrm{REPORT}$ and $\triangle \mathrm{E} \times \mathrm{REPORT}\left(\beta_{5}+\beta_{6}\right)$ is also positive and significant $(0.869, \mathrm{~F}=6.07)$. These results again indicate that the engagement of CSR affects the returns-earnings as sociation after controlling for the release of CSR reports. 
In Panel B of Table 5, $\beta_{1}+\beta_{2}$ in Model (2) is positive and highly significant $(0.679, \mathrm{~F}=373.50)$. Moreover, $\beta_{3}+\beta_{4}$ is also positive and significant $(0.215, \mathrm{~F}=41.13)$, consistent with the results of Table $4 . \beta_{5}+\beta_{6}$ is also positive and significant $(0.229, F=25.32)$. The results indicate that analysts count more on reported earnings in forecasting future earnings for companies ranked in the KEJI, reinforcing our primary results.

Table 5. Capital Market Perceptions: Controlling for the Issuance of CSR Report

\begin{tabular}{|c|c|c|c|}
\hline \multicolumn{4}{|c|}{ Panel A: Perceptions of Investors } \\
\hline Variable & Coefficient & Model (1) & Model (2) \\
\hline $\bar{E}$ & $\left(\beta_{1}\right)$ & $0.250(9.97)^{3 * *}$ & $0.383(11.64)^{* \pi}$ \\
\hline$\Delta \mathrm{E}$ & $\left(\beta_{2}\right)$ & $0.059(3.45)^{* * *}$ & $0.069(3.06)^{* * * *}$ \\
\hline & $\left(\beta_{1}+\beta_{2}\right)$ & $0.309(186.97)^{* * * *}$ & $0.452(233.71)^{* * * *}$ \\
\hline ExDCSR & $\left(\beta_{3}\right)$ & $0.632(5.18)$ & $0.751(6.26)$ \\
\hline$\triangle \mathrm{E} \times \mathrm{DCSR}$ & $\left(\beta_{4}\right)$ & $0.660(5.48)^{* * *}$ & $0.485(4.11)^{\text {*.*.* }}$ \\
\hline & $\left(\beta_{3}+\beta_{4}\right)$ & $1.292(124.19)^{* * * *}$ & $1.236(117.61)^{* * * *}$ \\
\hline E×REPORT & $\left(\beta_{5}\right)$ & $0.419(1.11)$ & $0.325(0.89)$ \\
\hline$\triangle \mathrm{E} \times \mathrm{REPORT}$ & $\left(\beta_{6}\right)$ & $0.601(2.26)^{\cdots-}$ & $0.544(2.11)^{\ldots-\ldots}$ \\
\hline & $\left(\beta_{5}+\beta_{6}\right)$ & $1.020(7.92)^{* * * *}$ & $0.869(6.07)^{* * *}$ \\
\hline Adj. $R^{2}$ & & 0.282 & 0.327 \\
\hline
\end{tabular}

Panel B: Perceptions of Financial Analy sts

\begin{tabular}{|c|c|c|c|}
\hline & & \multicolumn{2}{|c|}{ Dependent Variable $=$ FEPS } \\
\hline & Coefficients & Model (1) & Model (2) \\
\hline EPS & $\left(\beta_{1}\right)$ & $0.961(61.14)$ & $1.082(41.04)$ \\
\hline$\triangle \mathrm{EPS}$ & $\left(\beta_{2}\right)$ & $-0.494(-19.78)^{* * *}$ & $-0.403(-12.11)^{* * * *}$ \\
\hline & $\left(\beta_{1}+\beta_{2}\right)$ & $0.467(455.44)^{* * *}$ & $0.679(373.50)^{* * * 4}$ \\
\hline EPS $\times$ DCSR & $\left(\beta_{3}\right)$ & $0.039(1.87)^{*}$ & $-0.019(-0.97)$ \\
\hline$\triangle \mathrm{EPS} \times \mathrm{DCSR}$ & $\left(\beta_{4}\right)$ & $0.270(6.94)^{\ldots \ldots \ldots}$ & $0.234(6.29)$ \\
\hline & $\left(\beta_{3}+\beta_{4}\right)$ & $0.309(79.84)^{* * *}$ & $0.215(41.13)^{* * *}$ \\
\hline EPS $\times$ REPORT & $\left(\beta_{5}\right)$ & $0.046(1.99)^{n+\cdots}$ & $0.001(0.02)$ \\
\hline$\triangle \mathrm{EPS} \times \mathrm{REPORT}$ & $\left(\beta_{6}\right)$ & $0.180(3.78)^{* * *}$ & $0.228(4.64)^{* * *}$ \\
\hline & $\left(\beta_{5}+\beta_{6}\right)$ & $0.226(27.80)^{n+\cdots+1}$ & $0.229(25.32)^{n+\ldots}$ \\
\hline Adj. $\mathrm{R}^{2}$ & & 0.895 & 0.914 \\
\hline
\end{tabular}

Report: Indicator variable that equals one when a firm issues a CSR report and zero otherwise

The definitions of variables are provided in Table 1 . To save space, we do not report parameter estimates for the other variables.

$*, * * * * *$ indicate statistical significance at $p<0.10, p<0.05$, and $p<0.01$ levels, respectively, based on two-tailed tests.

\section{CONCLUSION}

This study provides insights into the recent debate surrounding CSR. We analyze the relationship between CSR and earnings quality as perceived by capital market participants. Based on the effect of firm engagement in CSR activity on perceived reliability of reported earnings, we infer how capital market participants view engagement in CSR activity as improving earnings quality. When all else is equal, if capital market participants perceive the signal of engagement in CSR activity as improving earnings quality, then they view reported financial statements as more reliable.

We analyze the perceptions of investors and financial analysts, primary users of accounting reports in the capital market. Employing a comprehensive sample of Korean firms during the 2002 to 2011 period, we find evidence supporting our hypotheses that investors and analysts see earnings quality to be higher with the commitment to CSR activity. Therefore, our results suggest that capital market participants perceive CSR as a signal of improved earnings quality.

An implication of this study is that capital market participants recognize the signal of commitment to CSR activity and have different perceptions of the informativeness of earnings from companies that engage in CSR activity and those that do not. 


\section{ACKNOWLEDGMENTS}

This work was supported by the National Research Foundation of Korea Grant funded by the Korean Government (NRF-2013S1A5A2A 01019085).

\section{AUTHOR BIOGRAPHIES}

Hyunjung Choi, Assistance Profess or, College of Social Sciences, Sungkyul University, Sungkyul University-ro 53, Manan-gu, Anyang-city, Gyeonggi-do, Republic of Korea. E-mail: hjchoi@sungkyul.ac.kr (First Author)

Doocheol Moon, Professor, School of Business, Yonsei University, 50 Yonsei-ro, Seodaemun-gu, Seoul 120-749, Republic of Korea. E-mail: dmoon@yonsei.ac.kr (Corresponding author)

\section{REFERENCES}

Ali, A., \& P. Zarowin. (1992). The Role of Earnings Levels in Annual Earnings-Returns Studies. Journal of Accounting Research, 30, 286-296.

American Institute of Certified Public Accountants(AICPA). (1994). Special Committee on Financial Reporting, Improving Business Reporting A Customer Focus : Meeting the Informational Needs of Investors and Creditors. New York, NY.

American Institute of Certified Public Accountants(AICPA). (2010). Sustainability Accounting and Reporting. Retrieved from http://www.aicpa.org/interestareas/businessindustry andgovernment/resources/sustainability/pages/sustainability faqs.as px.

Barron, O. E., D. By ard, C. Kile, \& E. J. Reidl. (2002). High Technology Intangibles and Analy sts' Forecasts. Journal of Accounting Research, 40, 289-12.

Becker, C. L., M. L. DeFond, J. Jiambalvo, \& K. R. Subramanyam. (1998). The Effect of Audit Quality on Earnings Management. Contemporary Accounting Research, 15(1), 1-24.

Beurden P., \& T. Gössling. (2008). The Worth of Values: A Literature Review on the Relation between Corporate Social and Financial Performance. Journal of Business Ethics, 82, 407-424.

Brown, L., R. Hagerman, P. Griffin, \& M.Zmijewski. (1987). Security Analy st Sup eriority Relative to Univariate Time-Series Models in Forecasting Quarterly Earnings. Journal of Accounting and Economics, 9, 61-7.

Burkett, B., J. Craig, S. Graham, \& Gallagher, S. (2006). Corporate Social Responsibility: An Evolving Global business Phenomenon. Heenan Blaikie: Canada.

Campbell, J., M. Lettau, G. Malkiel, \& Y. Xu. (2001). Have Individual Stocks Become More Volatile? An Empirical Exploration of Idiosyncratic Risk. Journal of Finance, 56, 1-43.

Campbell, Tim S., \& William A. Kracaw. (1980). Information Production, Market Signalling, and the Theory of Financial Intermediation. Journal of Finance, 35, 863-882.

Choi, H., \& D. Moon. (2013). The Relationship between Corporte Social Responsibility and Accounting Transparency. Korean Accounting Review, 38(1), 137-173.

Chun, M. L., \& C. S. Kim. (2010). The Impact of Persistent Corporate Social Responsibility on Firm Performance. Working Paper.

DeFond, M., \& Hung, M. (2003). An Empirical Analysis of Analysts' Cash Flow Forecasts. Journal of Accounting and Economics, 35, 73-100.

DeFond, M. L., \& J. Jiambalvo. (1994). Debt Covenant Violation and Manipulation of Accruals. Journal of Accounting and Economics, 17, 145-76.

Dhaliwal, D. S., O. Z. Li, \& A. T. Yang. (2011). Voluntary Non-financial Disclosure and the Cost of Equity Capital: The Initiation of Corporate Social Responsibility Reporting. The Accounting Review, 86, 59-100.

Dhaliwal, D. S., S. Radhakrishnan, \& A. T. Yang. (2012). Nonfinancial Disclosure and Analy st Forecast Accuracy: International Evidence on Corporate Social Responsibility Disclosure. The Accounting Review, 87(3), 723-759.

Dharan, B., \& B. Lev. (1993). The Valuation Consequence of Accounting Changes: A Multi-year Examination. Journal of Accounting, Auditing and Finance, 8, 475-495.

Easton, P., \& T. Harris. (1991). Earnings as an Explanatory Variable for Returns. Journal of Accounting Research, 29(Spring), 19-36.

Francis, J., \& L. Soffer. (1997). The Relative Informativeness of Analysts' Recommendations and Earnings Forecast Revisions. Journal of Accounting Research, 34, 193-212.

Friedman, M. (1970). The Social Responsibility of Business Is to Increase Its Profits. New York Times Magazine (September).

Ghosh, A., \& D. Moon. (2005). Auditor Tenure and Perceptions of Audit Quality. The Accounting Review, 80, 585-612.

Ghoul, S., O. Guedhami, C. Y. Kwok, \& D. R. Mishra. (2011). Does Corporate Social Responsibility Affect the Cost of Capital?. 
Journal of Banking and Finance, 35, 2388-2406.

Guiral, A. (2012). Corporate Social Performance, Innovation Intensity and Their Impacts on Financial Performance: Evidence from Lending Decisions. Behavioral Research in Accounting, 24(2), 65-85.

Hull, C. E., \& S. Rothenberg. (2008). Firm Performance: The Interactions of Corporate Social Performance with Innovation and Industry Differentiation. Strategic Management Journal, 29, 781-89.

Hwang, H. C. (2009). Value Relevance of Non-financial Information Focusing on the Corporate Social Responsibility. Korean Accounting Information Review, 27, 215-236.

International Federation of Accountants(IFAC). (2006a). Professional Accountants in Business: at the Heart of Sustainability? Professional Accountants in Business Committee.

International Federation of Accountants(IFAC). (2006b). Sustainability: The Role of the Professional Accountant in Business, Professional Accountants in Business Committee.

International Organization for Standardization(ISO). (2010). ISO 26000 Social Responsibility. Retrieved from http://www.iso.org/iso/discovering_iso_26000.pdf.

Ioannou, I., \& G. Serafeim, (2010). The Impact of Corporate Social Responsibility on Investment Recommendations. Working Paper. London Business School and Harvard Business School.

Kim, Y., M. S. Park, \& B. Wier. (2012). Is Earnings Quality Associated with Corporate Social Responsibility ? The Accounting Review, 87(3), 761-796.

Kim, Y. S., \& J. B. Wi. (2010). Corporate Social Responsibility and Firm's Financial Performance. Working Paper.

Lang, M., \& R. Lundholm. (1996). Corporate Disclosure Policy and Analy st Behavior. The Accounting Review, 71, 467-92.

Levitt, T. (1958). The Dangers of Social Responsibility. Harvard Business Review, 36, 41-50.

Linthicum, C., A. Reitenga, \& J. Sanchez. (2010). Social Responsibility and Corporate Reputation: The Case of the Arthur Andersen Enron Audit Failure. Journal of Accounting and Public Policy, 29 (2), 160-176.

Lys, T., J. P. Naughton, \& C. Wang. (2012). Siganlig Through Corporate Accountability Reporting. Working Paper. North Western University.

Margolis, J. D., \& J. P. Walsh. (2003). Misery Loves Companies: Rethinking Social Initiatives by Business. Administrative Science Quarterly, 48(2), 268-305.

McNichols, M. F., \& S. R. Stubben. (2008). Does Earnings Management Affect Firms' Investment Decision?. The Accounting Review, 83(6), 1571-1603.

Na, Y., \& S. Hong. (2011). An Empirical Analy sis on Value Relevance of Corporate Social Responsibility Activities by Firm Size. Koram Accounting Journal, 20(5), 125-160.

Oh, W. Y., Y. K. Chang, \& A. Martynov. (2011). The Effect of Ownership Structure on Corporate Social Responsibility : Empirical Evidence from Korea. Journal of Business Ethics, 104, 283-297.

Orlitzky, M.\& J. D. Benjamin. (2001). Corporate Social Performance and Firm Risk: A Meta-Analy tic Review. Business and Society, 40(4), 369-96.

Orlitzy, M., F. L. Schmidt, \& S. L. Rynes. (2003). Corporate Social and Financial Performance: A Metaanaly sis. Organization Studies, 24(3), 403-441.

Porter, M.E., \& M. R. Kramer. (2006). Strategy \& Society: The Link Between Competitive Advantage and Corporate Social Responsibility. Harvard Business Review, 1-16.

Schipper, K. (1991). Analysts' Forecasts. Accounting Horizons, 4, 105-21.

Schipper, K., \& L. Vincent. (2003). Earnings Quality. Accounting Horizons, 17, 97-10.

Spence, M. (1973). Job Market Signaling. Quarterly Journal of Economics, 87(3), 355-374.

Spence, M. (1974). Market Signaling. Cambridge: Harvard Business School Press.

Surroca, J., J. A. Tribo \& S. Waddock. (2010). Corporate Responsibility and Financial Performance: The Role of Intangible Resources. Strategic Management Journal, 31, 463-490.

Teoh, S. H., \& T. J. Wong. (1993). Auditor Size and the Earnings Response Coefficient. The Accounting Review, 68, 346-66.

Verschoor, C. (2005). Is There Financial Value in Corporate Values? Strategic Finance, 87 (1), 17-18.

Warfield, T., J. Wild, \& K. Wild. (1995). Managerial Ownership, Accounting Choices, and Informativeness of Earnings. Journal of Accounting and Economics, 20, 61-1.

Yook, K. H., \& M.H. Choi. (2011). Linking Financial Performance and Ownership Structure to Corporate Social Performance. The Study of Korean Accounting and Auditing, 53, 303-331. 


\section{NOTES}

